J. Clin. Chem. Clin. Biochem.

Vol. 25, 1987, pp. 879-888

(C) 1987 Walter de Gruyter \& Co.

Berlin - New York

\title{
Methods for the Determination of the Interferon-Induced Enzyme 2'-5' Oligoadenylate Synthetase in Mononuclear Blood Cells
}

\author{
By G. Bruchelt, J. Beck, Karin Schilbach-Stückle, Ewa Koscielniak, J. Treuner and D. Niethammer
}

Abteilung für Hämatologie und Onkologie, Universitätskinderklinik Tübingen

(Received December 9, 1986/August 28, 1987)

Summary: The determination of 2'-5'-oligoadenylate synthetase in peripheral blood mononuclear cells is used as a biological response parameter during therapy with interferon and in the diagnosis of diseases related to the interferon system. In this communication, some general aspects concerning the preparation of $2^{\prime}-5^{\prime}-$ oligoadenylate synthetase from peripheral blood mononuclear cells and the incubation conditions of the $2^{\prime}$ $5^{\prime}$-oligoadenylate synthetase reaction are reported. Four analytical procedures for the determination of the products formed during the $2^{\prime}-5^{\prime}$-oligoadenylate synthetase reaction were comparatively investigated and the advantages and limitations of the assays are discussed. As an example of possible clinical application, the levels of $2^{\prime}-5^{\prime}$-oligoadenylate synthetase were determined in the mononuclear cell fraction of peripheral blood from healthy persons as well as from children with chronic myelogenous leukaemia.

\section{Introduction}

Interferons are (glyco)proteins with pleiotropic effects (antiviral, antiproliferative, immunomodulative). The molecular mechanisms of their action is not yet fully understood, but some of the antiviral and perhaps antiproliferative effects are probably related to the so-called 2'-5'-oligoadenylate system $(1,2)$; treatment of cells with interferon leads to the de novo synthesis of $2^{\prime}$-5'-oligoadenylate synthetase (fig. 1). This enzyme is able to produce oligoadenylates from ATP in the presence of double-stranded RNA(dsRNA) according to the equation:

$$
\begin{aligned}
& \text { n } \mathrm{ATP} \Rightarrow \operatorname{ppp} 5^{\prime} \mathrm{A} 2^{\prime}\left(\mathrm{p} \overline{5}^{\prime} \mathrm{A}\right)_{\mathrm{n}-1}+(\mathrm{n}-1) \mathrm{PP}, \\
& (\mathrm{n}=2-14)
\end{aligned}
$$

The adenosine residues of these oligoadenylates are linked by phosphodiester bonds in the unusual 2'-5'position. $2^{\prime}-5^{\prime}$-Oligoadenylates greater than the dimeric form $(n=2)$ activate an endoribonuclease (RNaseL) which cleaves mRNA. A third enzyme, 2'$5^{\prime}$-oligoadenylate phosphodiesterase, destroys $2 '-5^{\prime}-$ oligoadenylates, so that the RNase returns to its inactive state. Additionally to $2^{\prime}-5^{\prime}$-oligoadenylates, $2^{\prime}$ 5 '-oligoadenylate-cores ( 2 '-5'-oligoadenylates without the triphosphate residues on the terminal $5^{\prime}$-position) are also found in cells. They do not activate the endoribonuclease, but they are also biologically active (3).

The cellular levels of the 2'-5'-oligoadenylate synthetase are subject to change under certain conditions, e. g. during differentiation (4). It shows an especially marked elevation after interferon treatment. Therefore, the determination of 2 '-5'-oligoadenylate synthetase has been widely used in the diagnosis of different diseases connected with the interferon system $(5-12)$ and as a response parameter during interferon therapy $(13,14)$. Several methods for the determination of 2'$5^{\prime}$-oligoadenylate synthetase in different cell types have been described (for review see l.c. (1)). All these assays consist of three steps: preparation of $2^{\prime}-5^{\prime}-$ oligoadenylate synthetase from cells, incubation of the enzyme with ATP and analysis of the reaction products. However, because several different analytical procedures are used and incubation conditions are not uniform, greatly differing results have been reported (factor 10). The aim of our study was to standardize the preparation and incubation conditions for the determination of $2^{\prime}-5^{\prime}$-oligoadenylate 


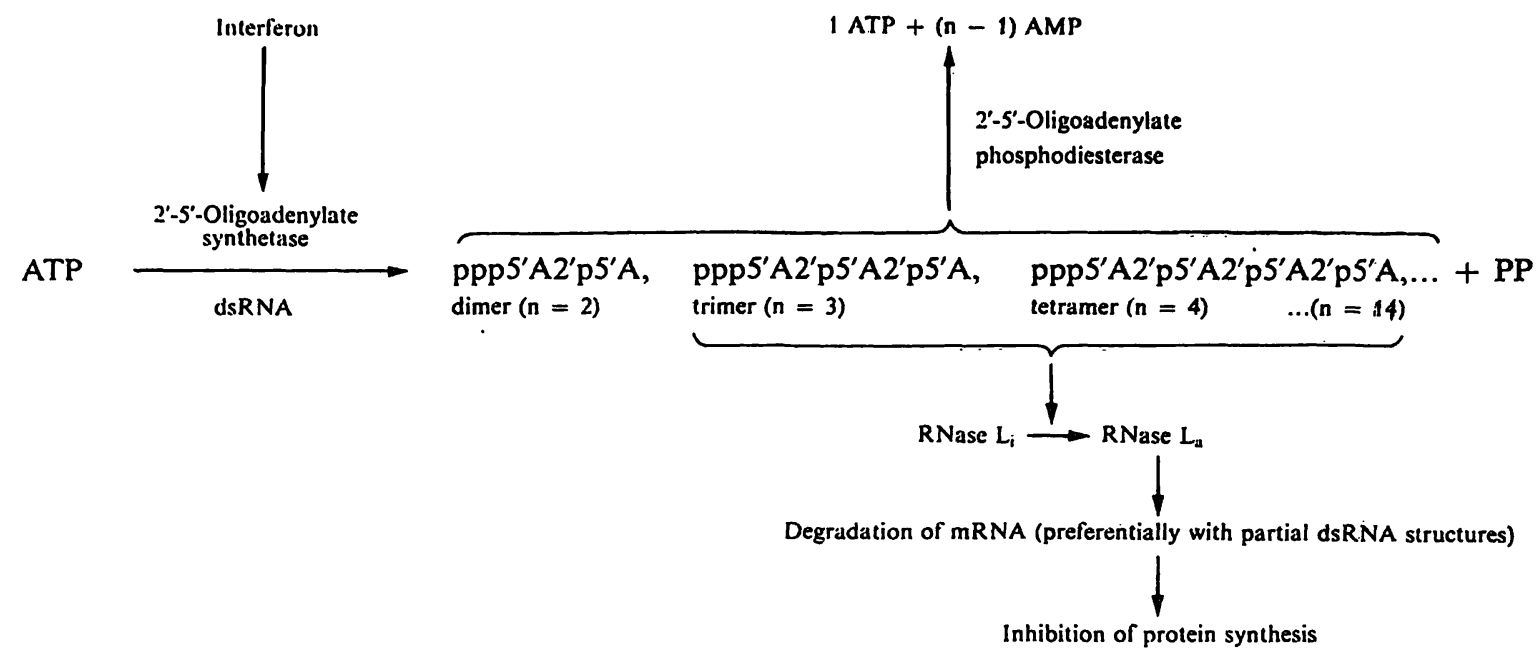

Fig. 1. The 2'-5'-oligoadenylate system.

synthetase in peripheral blood mononuclear cells, and to compare the test system according to Schattner (which is widely used in many laboratories) with some other assays in order to find out which of them is most suitable for application in the clinical laboratory. $2^{\prime}$-5'-Oligoadenylate synthetase levels were estimated in peripheral blood mononuclear cells from healthy persons. As an example of a clinical application, they were also estimated in children with chronic myelogenous leukaemia.

\section{Materials and Methods}

\section{Materials}

Enzymes (from Sigma, München)':

1) Bacterial alkaline phosphatase, $E$. coli, type III, EC 3.1.3.1.

2) Snake venom phosphodiesterase, EC 3.1.4.1.

3) Creatine phosphokinase, bovine heart, type III, EC 2.7.3.2.

4) Hexokinase, bakers veast, type IV, EC 2.7.1.1.

Interferon- $\alpha$, Polyferon, $3.3 \times 10^{6} \mathrm{U} / \mathrm{mg}$ protein, Bioferon, Laupheim

Agarose-Polyriboinosinic acid-Polyribocytidylic acid (AGPOLY(I)-POLY(C)), type 6, Pharmacia, Freiburg, (Poly(rI):(rC))-agarose beads

Rabbit reticulocyte lysate N 90, Amersham, Braunschweig 2'-5'-Adenosine-tetramer 5'-triphosphate, Amersham, Braunschweig

1) 1. Bacterial alkaline phosphatase, E. coli, type III, Orthophosphoric-monoester phosphohydrolase (EC 3.1.3.1)

2. Creatine phosphokinase, bovine heart, type III, ATP: creatine N-phosphotransferase (EC 2.7.3.2)

3. Hexokinase, bakers yeast, type IV, ATP:D-hexose-6-phosphotransferase (EC 2.7.1.1)

4. Snake venom phosphodiesterase, $5^{\prime}$-Exonuclease; Oligonucleate 5'nucleotido-hydrolase (EC 3.1.4.1)
Radioactive-labelled compounds (Amersham, Braunschweig):

1) Adenosine $\left[5^{\prime}-\alpha{ }^{32} \mathrm{P}\right]$-triphosphate, $\left[{ }^{22} \mathrm{P}\right] \mathrm{ATP}, 0.37-1.85 \mathrm{TBq} /$ $\mathrm{mmol}$

2) $\left[2,8-{ }^{3} \mathrm{H}\right]$ Adenosine $5^{\prime}$-triphosphate, $\left[{ }^{3} \mathrm{H}\right] \mathrm{ATP}, 1.1-1.85 \mathrm{TBq} /$ $\mathrm{mmol}$

3) $2^{\prime}-5^{\prime}$-Adenosine tetramer $5^{\prime}$-triphosphate, $\left[{ }^{32} \mathrm{P}\right] \mathrm{pCp} 3^{\prime}$-end labeled (ppp5'A2'p5'A2'p5'A2'p5 $\left.5^{\prime} 3^{\prime}{ }^{32} \mathrm{P}\right] \mathrm{p} 5^{\prime}{ }^{\prime} 3^{\prime} \mathrm{p}, \quad$ abbr.: 2-5A [ $\left.{ }^{32} \mathrm{P}\right] \mathrm{pCp}$

\section{Buffers}

1) Lysis buffer: $20 \mathrm{mmol} / 1 \mathrm{HEPES}, 5 \mathrm{mmol} / \mathrm{l}$ magnesium acetate, $120 \mathrm{mmol} / 1$ potassium chloride, $7 \mathrm{mmol} / 1$ sodium hydrosulphite, glycerol, volume fraction 0.1 , Nonidet P-40, volume fraction 0.005 , $\mathrm{pH} 7.5$.

2) Buffer A: $10 \mathrm{mmol} / \mathrm{l}$ HEPES, $50 \mathrm{mmol} / 1$ potassium chloride, $7 \mathrm{mmol} / \mathrm{l}$ sodium hydrosulphite, $20 \mathrm{mmol} / 1$ magnesium acetate, glycerol, volume fraction $0.2, \mathrm{pH} 7.6$.

3) Buffer B: Buffer $A+$ creatine phosphokinase (3 g/l), creatine phosphate $(10 \mathrm{mmol} / \mathrm{l})$, adenosine triphosphate $(5 \mathrm{mmol} / \mathrm{l}), \mathrm{pH} 7.6$ (frozen in aliquots at $-70^{\circ} \mathrm{C}$ ).

4) Incubation buffer 1 : Buffer $\mathrm{B}+1.85 \mathrm{GBq} / \mathrm{l}\left[{ }^{32} \mathrm{P}\right] \mathrm{ATP}$ (Schattner-assay).

5) Incubation buffer 2: Buffer B $+1.85 \mathrm{GBq} / \mathrm{l}\left[{ }^{\mathrm{H}} \mathrm{H}\right] \mathrm{ATP}$ (Lodemann/Ball \& White assay).

6) Radiobinding assay buffer 1: $85 \mathrm{mmol} / 1$ potassium chloride, $20 \mathrm{mmol} / 1 \mathrm{Tris} \cdot \mathrm{HCl}, 5 \mathrm{mmol} / \mathrm{l}$ magnesium acetate, $1 \mathrm{mmol} / 1$ adenosine triphosphate, glycerol, volume fraction $0.05, \mathrm{pH}$ 7.6.

7) Radiobinding assay buffer 2: Buffer 1 minus adenosine triphosphate.

\section{Methods}

In figure 2, a schematic survey of the test systems described subsequently is given.

\section{Preparation of cell lysates}

Peripheral blood mononuclear cells werẽ isolatèd ưsing lymphoprep (Nyegaard, Oslo). The isolated cells were suspended in MEM (minimal essential medium containing $5 \%$ foetal calf serum). The cell suspension $\left(1 \times 10^{6}\right.$ cells per $\left.\mathrm{ml}\right)$ was incubated at ${ }^{\circ} 37^{\circ} \mathrm{C}$ overnight without or with $10,00 \mathrm{U} / \mathrm{ml}$ interferon- $\alpha$. 

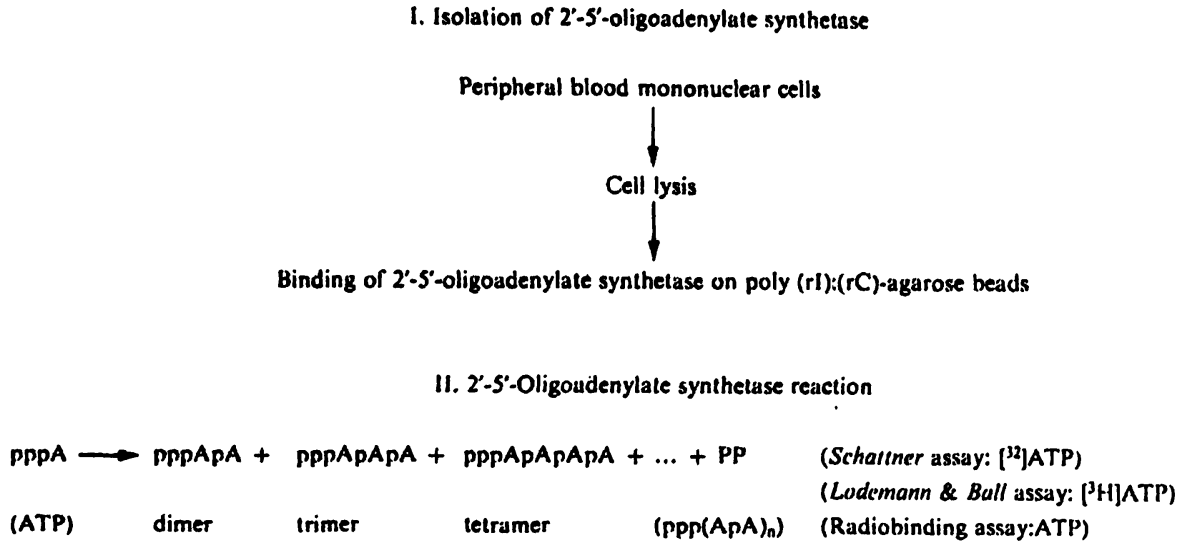

III. Analysis of reaction products
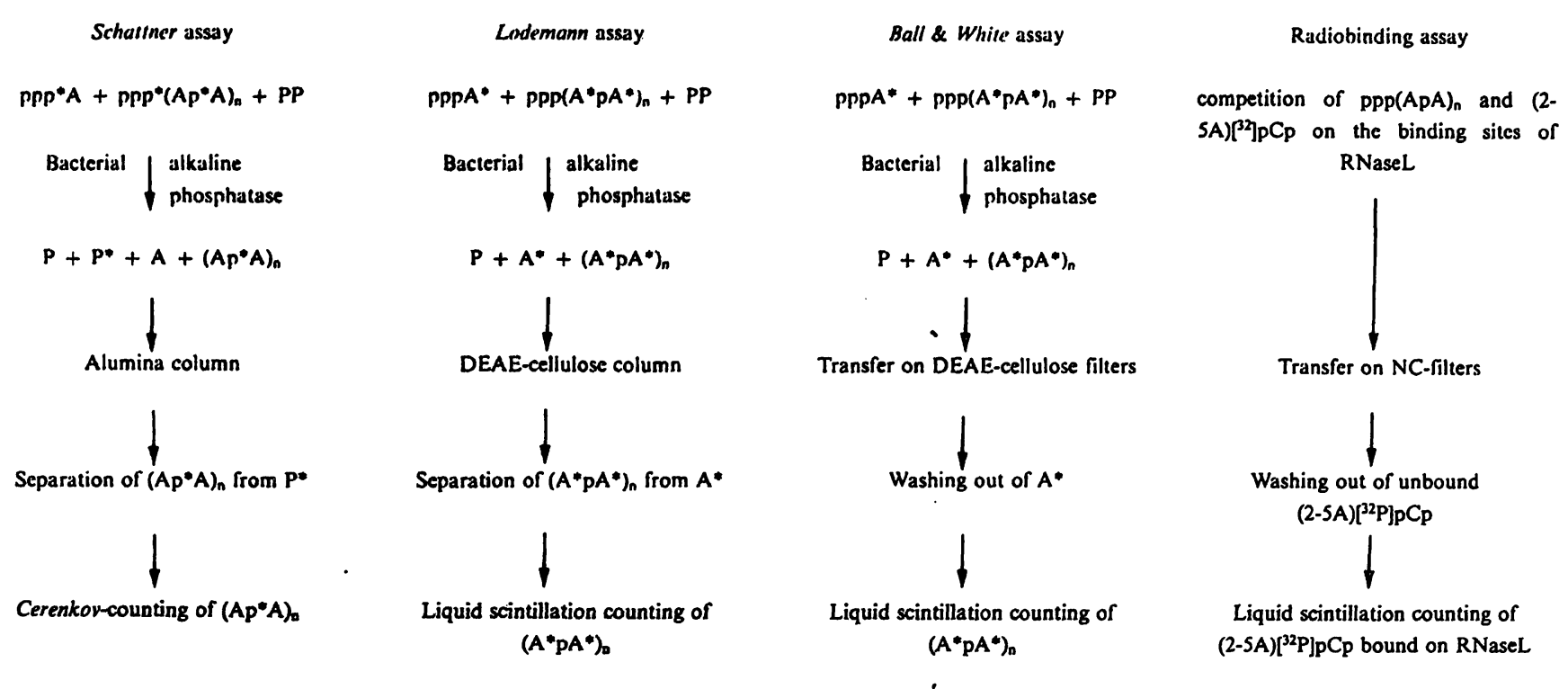

Fig. 2. Comparative survey of the 4 test systems investigated for the determination of $2^{\prime}-5^{\prime}$-oligoadenylate synthetase.

After centrifugation, the supernatant was removed completely and the cell pellets were treated with lysis buffer $(100 \mu \mathrm{l}$ per $2 \times 10^{6}$ cells, 10 minutes at $\left.4^{\circ} \mathrm{C}\right)$. After centrifugation $(15000 \mathrm{~g}$, 8 minutes), the $2^{\prime}-5^{\prime}$-oligoadenylate synthetase-containing supernatant was collected and frozen at $-70^{\circ} \mathrm{C}$.

Binding of $2^{\prime}-5^{\prime}$-oligoadenylate synthetase on poly(rI):(rC)-agarose beads and performance of the $2^{\prime}-5^{\prime}$-oligoadenylate synthetase reaction

Poly(rI):(rC)-agarose beads were washed' with $20 \mathrm{mmol} / \mathrm{l}$ sodium phosphate buffer containing 200.mmol/1 sodium chloride, pH 7.5 (this step, however, can be avoided). The beads were suspended in buffer $A(1+1$ by vol.) and $40 \mu l$ aliquots were transferred into Eppendorf cups. After brief centrifugation and removal of the supernatant, $20 \mu \mathrm{l}$ cell extracts were added ( 25 minutes incubation at room temperature). Following this binding reaction, the agarose-beads were washed twice with $750 \mu l$ buffer $A$. The $2^{\prime}-5^{\prime}$-oligoadenylate synthetase reaction was started by addition of incubation buffer $(20 \mu \mathrm{l})$, and the incubation was carried out for $2-20$ hours at $30^{\circ} \mathrm{C}$. The reaction was stopped by heating the samples $\left(2\right.$ minutes at $\left.95^{\circ} \mathrm{C}\right)$.

Until this step, the test procedure is the same for all four methọds described.
Analysis of the $2^{\prime}-5^{\prime}$-oligoadenylates formed during the $2^{\prime}-5^{\prime}$-oligoadenylate synthetase reaction

All assays were carried out according to the original test protocols, with small modifications.

\section{Schattner assay (16) (standard and reference test system)}

After the $2^{\prime}-5^{\prime}$-oligoadenylate synthetase reaction, $20 \mu$ l bacterial alkaline phosphatase (100 U/ml Trizma $(140 \mathrm{mmol} / \mathrm{l}$; Sigma, München) were added to the reaction vessels (1 hour incubation time at $37^{\circ} \mathrm{C}$ ). This step is carried out in the same way as in the assays of Lodemann \& Ball (see below and fig. 2).

After incubation with bacterial alkaline phosphatase, the [ $\left.{ }^{32} \mathrm{P}\right]-$ labelled $2^{\prime}-5^{\prime}$-oligoadenylate cores were separated from $\left[{ }^{32} \mathrm{P}\right]$ on small columns, which were prepared in $1 \mathrm{ml}$ Eppendorf standard tips using $600 \mu \mathrm{l}$ alumina suspension (alumina, type WA4: acid; Sigma, München, suspended in water, $1+1$ by vol.). The columns were washed with $3 \mathrm{ml}$ glycine- $\mathrm{HCl}(1 \mathrm{~mol} / \mathrm{l}$, $\mathrm{pH} 2)$. Samples $(20 \mu \mathrm{l})$ were applied to the columns, and the $2^{\prime}-5^{\prime}$-oligoadenylate cores were eluted with $3 \mathrm{ml}$ glycine- $\mathrm{HCl}$ and their radioactivity determined (Cerenkov-radiation).

\section{Principles of evaluation of the Schattner assay}

Because of the short half-life time of ${ }^{32} \mathrm{P}$ (14.31 days), the performance of one set of experiments was carried out within 
2-4 weeks (usually $5 \times 50$ determinations in duplicate using $\left.5 \times 1.85 \mathrm{MBq}\left[{ }^{32} \mathrm{P}\right] \mathrm{ATP}\right)$. For each set of experiments, the $2^{\prime}-$ 5 -oligoadenylate synthetase activities in peripheral blood mononuclear cells of 5 healthy persons (male and female, 20 45 years of age) were detcrmined (normal collective). The cells were left untreated, or they were pretreated with 1000 IU interferon. The $2^{\prime}-5$-oligoadenylate synthetase was determined as described above. Each test protocol consisted of:

a) $100 \%$-sample: $20 \mu \mathrm{l}$ radioactive cocktail (20 $\mu$ lincubation buffer $+20 \mu \mathrm{l}$ Trizma), suspended in $3 \mathrm{ml}$ glycine- $\mathrm{HCl}$.

b) test samples: radiolabeled $2^{\prime}-5^{\prime}$-oligoadenylate cores, eluted with $3 \mathrm{ml}$ glycine- $\mathrm{HCl}$ (as described above)

c) blank sample: samples processed exactly as test samples, but using $20 \mu \mathrm{l}$ lysis buffer instead of $20 \mu \mathrm{l}$ cell lysate.

The incorporation of $\left[{ }^{32} \mathrm{P}\right]$ from $\left[{ }^{32} \mathrm{P}\right] \mathrm{ATP}$ into $22^{\prime}-5^{\prime}$-oligoadenylate cores was estimated, e.g. after 20 hours incubation time. The results are expressed as:

$\%$ radioactivity incorporated from $\left[{ }^{32}\right.$ P]ATP into $2^{\prime}-5^{\prime}$-oligoadenylate cores per hour from a lysate of $10^{6}$ cells.

The mean value from 5 healthy donors (normal collective) was arbitrarily set at 1.0. 2'-5'-oligoadenylate synthetase activity present in the cell lysate from one of these 5 donors was adjusted to this mean value by sample dilution. Aliquots of this sample were frozen at $-70^{\circ} \mathrm{C}$ and were subsequently used as an internal reference sample for all further investigations using the same charge of $\left[{ }^{32} \mathrm{P}\right]$ ATP.

Additionally, the $2^{\prime}-5^{\prime}$-oligoadenylate synthetase activity was estimated in peripheral blood mononuclear cells after in vitro treatment with interferon (18 hours).

The ratio:

$$
\frac{\text { activity after interferon treatment }}{\text { activity without interferon treatment }}
$$

is expressed as the elevation factor.

\section{Lodemann assay (14)}

After treatment with bacterial alkaline phosphatase (see above), samples were diluted with $1 \mathrm{ml}$ Tris- $\mathrm{HCl}(0.5 \mathrm{mmol} / \mathrm{l}), \mathrm{pH} 7.6$. Following centrifugation, $1 \mathrm{ml}$ of the supernatant was applied to DEAE-52 cellulose columns (Whatman DE 52), prepared in $1 \mathrm{ml}$ plastic syringes (packing volume: $600 \mu \mathrm{l}$ ). The columns were equilibrated with Tris- $\mathrm{HCl}, \mathrm{pH}$ 7.6.

After addition of $15 \mathrm{ml} 0.5 \mathrm{mmol} / \mathrm{l}$ Tris- $\mathrm{HCl}, \mathrm{pH} 7.6$ (elution of $\left[{ }^{3} \mathrm{H}\right]$ adenosine), the $2^{\prime}-5^{\prime}$-oligoadenylate cores were eluted with $3 \mathrm{ml}$ buffer $(0.5 \mathrm{mmol} / \mathrm{l}$ Tris- $\mathrm{HCl}, 0.2 \mathrm{~mol} / 1 \mathrm{NaCl}, \mathrm{pH} 7.6)$. $1 \mathrm{ml}$ aliquots were mixed with $10 \mathrm{ml}$ scintillation cocktail (Unisolve 100, Zinsser, Frankfurt), and counted.

\section{Ball \& White assay (17)}

After treatment with bacterial alkaline phosphatase, $10 \mu \mathrm{l}$ samples were spotted onto $1 \mathrm{~cm}^{2}$ DEAE-cellulose paper (Whatman, DE 81), washed 8 times with distilled water and transferred into scintillation vials. $\left[{ }^{3} \mathrm{H}\right]$-labeled $2 '-5$-oligoadenylate cores, bound on the filters, were eluted with $300 \mathrm{mmol} / \mathrm{l} \mathrm{KCl}$. The radioactivity was measured after addition of $10 \mathrm{ml}$ Unisolve.

\section{Radiobinding assay (15)}

For test performance, the following were added to Eppendorf tubes:

a) $20 \mu \mathrm{l}$ rabbit reticulocyte lysate (contains RNaseL)

b) $10 \mu \mathrm{l} 2-5 \mathrm{~A}\left[{ }^{32} \mathrm{P}\right.$ ]pCp prediluted in buffer 1 , to achieve a radioactive concentration of about $2 \times 10^{4}$ counts $/ \mathrm{min}$ $10 \mu \mathrm{l}$ c) 1-20 $\mu \mathrm{l}$ sample (supernatant of the $2^{\prime}-5^{\prime}$-oligoadenylate synthetase reaction, diluted in distilled water). For establishment of the calibration curve, $1-20 \mu l 2^{\prime}-5^{\prime}$-adenylate tetramer $(1-5 \mathrm{nmol})$ were added instead of samples

d) Distilled water to a final test volume of $50 \mu \mathrm{l}$.

The tubes were incubated at $4{ }^{\circ} \mathrm{C}$ for 90 minutes. Subsequenlty, the incubation mixture was transferred to nitrocellulose filters, removed by suction, and the filters washed three times with $1 \mathrm{ml}$ of buffer 2 . Radioactivity on the filter discs (2-5A $\left[{ }^{32} \mathrm{P}\right] p \mathrm{Cp}$ bound on $\mathrm{RNaseL}$ ) was counted after addition of 10 $\mathrm{ml}$ Unisolve 100.

\section{Results}

Isolation of $2^{\prime}-5^{\prime}$-oligoadenylate synthetase from lysates of peripheral blood mononuclear cells using poly(rI):(rC)-agarose beads

Experiments were performed to determine the amount of poly(rI):(rC)-agarose suspension required to bind the $2^{\prime}-5^{\prime}$-oligoadenylate synthetase present in cell lysates. As depicted in figure $3,30 \mu$ were sufficient to bind the enzyme in cell lysates from $4 \times 10^{5}$ peripheral blood mononuclear cells pretreated with $1000 \mathrm{IU}$ interferon- $\alpha$ per $\mathrm{ml}$.

Furthermore, we investigated whether enzymes that attack either ATP or $2^{\prime}-5^{\prime}$-oligoadenylates can influence the $2^{\prime}-5^{\prime}$-oligoadenylate synthetase reaction if they are isolated as impurities on the poly(rI):(rC)agarose. As a model system for ATP-consuming enzymes, hexokinase (in the presence of $1 \mathrm{mmol} / 1 \mathrm{glu}-$ cose) was added to the $2^{\prime}-5^{\prime}$-oligoadenylate synthetase reaction mixture. Table $1 \mathrm{a}$ shows that ADP formed by the hexokinase reaction was reconverted completely to ATP in the presence of creatine phosphate and creatine kinase. These reagents are therefore added to the incubation buffer as an ATP-regenerating system.

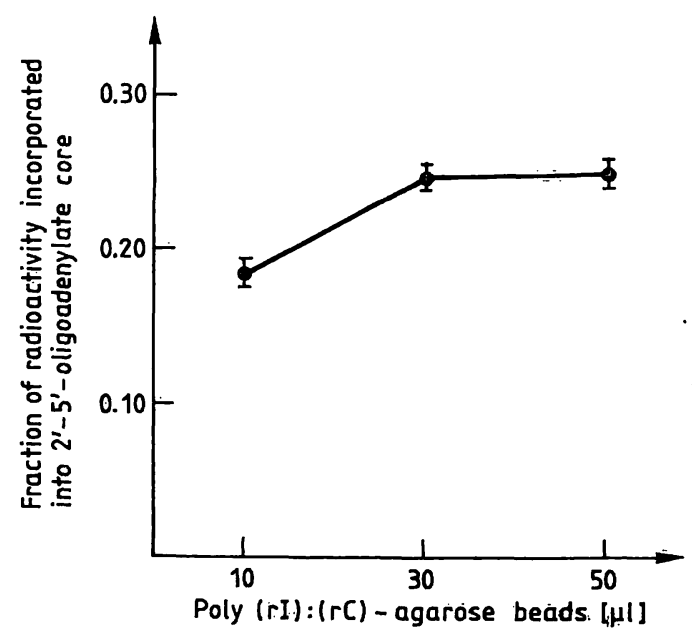

Fig. 3. Binding of 2 '-5'-oligoadenylate synthetase (lysate from $4 \times 10^{5}$ peripheral blood mononuclear cells, pretreated with $1000 \mathrm{IU}$ interferon- $\alpha$ ) on different amounts of poly (rI):(rC)-agarose beads (Schattner assay). 
Tab. 1 a. Degradation of ATP (5 mmol/l) by hexokinase and glucose $(1 \mathrm{mmol} / \mathrm{l})$

a) in the absence

b) in the presence of an ATP regenerating system (10 mmol/l creatine phosphate $+100 \mathrm{kU} / \mathrm{l}$ creatine kinase)

(30 minutes incubation time at $37^{\circ} \mathrm{C}$ )

\begin{tabular}{lll}
\hline Hexokinase $(\mathrm{kU} / \mathrm{l})$ & $\mathrm{a}$ & $\mathrm{b}$ \\
\hline 1 & $10.4 \%$ & $0 \%$ \\
10 & $20.4 \%$ & $0 \%$ \\
\hline
\end{tabular}

Tab. 1 b. Degradation of $2^{\prime}-5^{\prime}$-oligoadenylate cores during 1 hour incubation with peripheral blood mononuclear cell lysates (pretreated without or with $1000 \mathrm{U}$ interferon- $\alpha$ per $\mathrm{ml}$ ) and with snake venom phosphodiesterase as positive control.

Snake venom phosphodiesterase: $0.02 \mathrm{U}$ per test Cell lysate: $20 \mu \mathrm{l}\left(2 \times 10^{7}\right.$ cells per $\left.\mathrm{ml}\right)$ per test

Samples with potential

2'-5'-oligoadenylate

phosphodiesterase activity

Cell lysate with interferon- $\alpha$

Cell lysate without interferon- $\alpha$

Snake venom phosphodiesterase

$0-4 \%$

$0-4 \%$

$100 \%$ cores
Degradation of 2'-5'-oligoadenylate

In order to clarify whether any bound 2 '-5'-oligoadenylate phosphodiesterase activity could influence the $2^{\prime}-5^{\prime}$-oligoadenylate synthetase reaction, lysates of peripheral mononuclear blood cells and snake venom phosphodiesterase, known to be able to split 2'-5'oligoadenylates (18), were added to the incubation mixture after stopping the $2^{\prime}$-5'-oligoadenylate synthetase reaction. Table $1 \mathrm{~b}$ shows that degradation occurs only in the presence of snake venom phosphodiesterase (positive control), but not in the presence of cell lysate.
Time and concentration dependence of the 2 '-5'-oligoadenylate synthetase reaction

Under standard incubation conditions, the 2 '-5'-oligoadenylate synthetase reaction follows a linear course for at least 20 hours, if the enzyme is bound to poly(rI):(rC)-agarose beads (fig. $4 \mathrm{a}$ ).

Figure $4 \mathrm{~b}$ shows that there is also a linear correlation between the turnover rate and the amount of cell lysate (i. e. the amount of $2^{\prime}-5^{\prime}$-oligoadenylate synthetase).
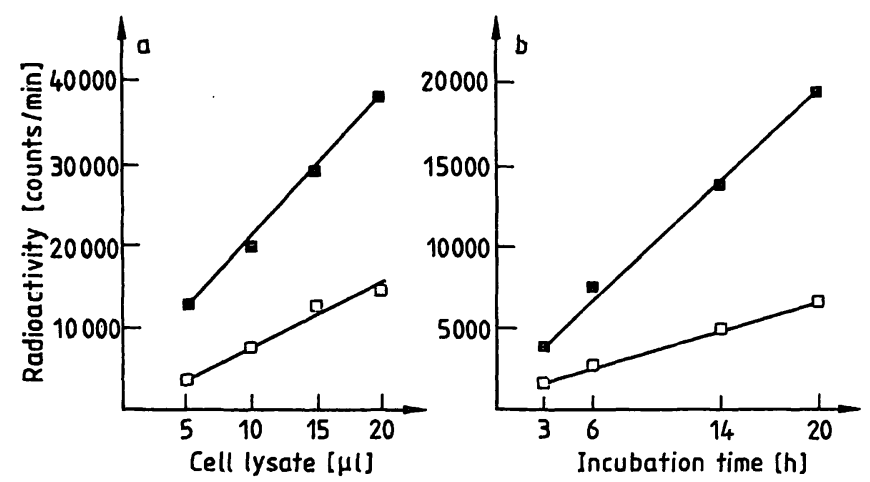

Fig. 4 a. Time dependence of the incorporation of radioactivity from [ $\left.{ }^{32} \mathrm{P}\right] \mathrm{ATP}$ into $2^{\prime}-5^{\prime}$-oligoadenylate cores $(20 \mu \mathrm{l}$ lysate from peripheral blood mononuclear cells, $2 \times 10^{6}$ cells per $\left.100 \mu l\right)$, (Schattner assay).

- - Cells pretreated with interferon overnight $\square-\square$ cells incubated in cell culture medium overnight

Fig. 4 b. $2^{\prime}-5^{\prime}$-Oligoadenylate synthetase activity (expressed as radioactivity incorporated from [ $\left.{ }^{32} \mathrm{P}\right] \mathrm{ATP}$ into $2^{\prime}-5^{\prime}$ oligoadenylate cores using different amounts of cell lysates from peripheral blood mononuclear cells $\left(2 \times 10^{6}\right.$ cells per $\left.100 \mu \mathrm{l}\right)$, (Schattner assay).

$\square-\square$ cells pretreated with interferon overnight $\square \rightarrow \square$ cells incubated in cell culture medium overnight

\section{Evaluation of the Schattner assay}

In table 2 , the turnover rate of the $2^{\prime}-5^{\prime}$-oligoadenylate synthetase reaction using the cell lysates of 5 healthy donors is given. All experiments were carried out in

Tab. 2. 2'-5'-Oligoadenylate synthetase levels in peripheral blood mononuclear cells from healthy donors without and after treatment with interferon- $\alpha(1000 \mathrm{I} U \dot{U} / \mathrm{ml})$

\begin{tabular}{|c|c|c|c|c|c|}
\hline Donor & $\begin{array}{l}\text { Radioactivity } \\
\text { counts/min per } \\
4 \times 10^{5} \text { cells per } 20 \mathrm{~h} \\
\text { (without interferon- } \alpha \text { ) }\end{array}$ & $\begin{array}{l}\text { Radioactivity } \\
\text { incorporated into } \\
2^{\prime}-5^{\prime} \text {-oligoadenylate } \\
\text { cores }(\%)\end{array}$ & $\begin{array}{l}\text { Radioactivity } \\
\text { counts/min per } \\
4 \times 10^{5} \text { cells per } 20 \mathrm{~h} \\
\text { (after interferon- } \alpha \\
\text { treatment) }\end{array}$ & $\begin{array}{l}\text { Radioactivity } \\
\text { incorporated into } \\
2^{\prime}-5^{\prime} \text {-oligoadenylate } \\
\text { cores }(\%)\end{array}$ & $\begin{array}{l}\text { Elevation } \\
\text { factor }\end{array}$ \\
\hline $\begin{array}{l}1 \\
2 \\
3 \\
4 \\
5\end{array}$ & $\begin{array}{l}22759 \pm 1941 \\
16096 \pm 666 \\
21547 \pm 513 \\
24648 \pm 1869 \\
18141 \pm 2164\end{array}$ & $\begin{array}{r}10.4 \\
7.3 \\
9.8 \\
11.3 \\
8.3\end{array}$ & $\begin{array}{l}56202 \pm 4458 \\
39828 \pm 1981 \\
53314 \pm 4211 \\
45644 \pm 1783 \\
41717 \pm 2198\end{array}$ & $\begin{array}{l}25.2 \\
18.2 \\
24.3 \\
20.8 \\
19.0\end{array}$ & $\begin{array}{l}2.42 \\
2.47 \\
2.47 \\
1.85 \\
2.30\end{array}$ \\
\hline$\overline{\mathbf{x}}$ & $20638 \pm 3474$ & $9.42 \pm 1.6$ & $47341 \pm 7161$ & $21.5 \pm 3.1$ & $2.3 \pm 0.26$ \\
\hline
\end{tabular}

$100 \%$-value: $219014 \pm 1857$

Blank value: $668 \pm 14$

Mean value of samples: $1.18 \pm 0.2 \%$ radioactivity incorporated into $2^{\prime}$-5'-oligoadenylate cores per hour per $1 \times 10^{6}$ cells (arbitrarily set: 1.0 )

Elevation factor: $2.3 \pm 0.26$ 
duplicate (CV was usually between 5 and $10 \%$ ). The mean basal level of the $2^{\prime}$ - $5^{\prime}$-oligoadenylate synthetase activity in this set of experiments was $1.18 \pm 0.2 \%$ radioactivity incorporated into 2 '-5'-oligoadenylate cores per hour per $10^{6}$ cells (CV: $16.8 \%$ ). This value was arbitrarily set as 1.0 and was used as the reference for all other determinations during a range of experiments carried out with the same charge of $\left[\alpha{ }^{32} \mathrm{P}\right] \mathrm{ATP}$. The elevation factor was $2.3 \pm 0.26$ (CV: $11.3 \%$ ).

In two other series of experiments carried out in the same way, using cell lysates of 5 other healthy persons and other charges of $\left[{ }^{-32} \mathrm{P}\right] \mathrm{ATP}$, the basal turnover rates were $0.635(\mathrm{CV}: 24.6 \%)$ and $0.713(\mathrm{CV}: 16.7 \%)$; the corresponding elevation factors were 2.9 (CV: $27.5 \%)$ and 3.2 (CV: $12.5 \%)$, respectively.

Day to day variation: The $2 '-5$-oligoadenylate synthetase activity in cell lysates from two healthy donors was determined three and four times during a oneweek period. The turnover rates obtained for the first person were $0.49,0.59$, and 0.41 (mean: $0.496 \pm 0.07$ ), $\mathrm{CV}: 14.8 \%$, and for the second person $0.865,0.915$, 0.76 , and 0.78 (mean: $0.83 \pm 0.06$ ), $\mathrm{CV}: 7.6 \%$ ).

Finally, peripheral blood mononuclear cells from one person were collected six times during a time period of two months. The coefficient of variation of the 2'$5^{\prime}$-oligoadenylate synthetase levels in these cell lysates was $24.2 \%$. In this case, the $2^{\prime}-5^{\prime}$-oligoadenylate synthetase activity of all six samples was estimated on the same day.

Comparison of the $2^{\prime}-5^{\prime}$-oligoadenylate synthetase assay according to Schattner with other assays

\section{Comparison between the Schattner assay (16) and the assays of Lodemann (14) and Ball (17)}

The common feature of these three assays is that $2^{\prime}$ $5^{\prime}$-oligoadenylates formed during the $2^{\prime}$ - $5^{\prime}$-oligoadenylate synthetase reaction are converted into the corresponding 2 '-5'-oligoadenylate cores by treatment with bacterial alkaline phosphatase (fig. 2); this allows an easier separation of the reaction products. Table 3 shows that the $2^{\prime}-5^{\prime}$-oligoadenylate synthetase levels obtained with the Schattner assay are lower than those of the two other assays. This reflects the situation that in the Schattner assay part of the radioactivity incorporated from $\left[{ }^{32} \mathrm{P}\right]$ ATP into $2 '-5$-oligoadenylates is eliminated during treatment with bacterial alkaline phosphatase $\left(\left[{ }^{32} \mathrm{P}\right]\right.$ on the $5^{\prime}$-end of $2^{\prime}-5^{\prime}$-oligoadenylates). In contrast, there is no loss of radioactivity in the Lodemann \& Ball assay because $\left[{ }^{3} \mathrm{H}\right]$ adenosinelabeled ATP is used as the substrate of the $2^{\prime}-5^{\prime}$ oligoadenylate synthetase reaction.
Tab. 3. Comparison of the radioactivity incorporated into $2^{\prime}$ $5^{\prime}$-oligoadenylate cores using the assays according to Schattner, Lodemann and Ball

\begin{tabular}{lrrr}
\hline Cell lysate & $\begin{array}{l}\text { Schattier } \\
\text { assay }\end{array}$ & $\begin{array}{l}\text { Lodemann } \\
\text { assay }\end{array}$ & $\begin{array}{l}\text { Ball } \\
\text { assay }\end{array}$ \\
\hline without interferon- $\alpha$ & & $i$ & \\
$15 \mu l$ & $2.3 \pm 0.15$ & $2.8 \pm 0.92$ & background \\
$30 \mu l$ & $5.1 \pm 0.33$ & $5.5 \pm 0.98$ & $8.0 \pm 0.7$ \\
with interferon- $\alpha$ & & & \\
$15 \mu l$ & $6.1 \pm 0.76$ & $9.8 \pm 0.6$ & $9.4 \pm 0.8$ \\
$30 \mu l$ & $14.1 \pm 1.27$ & $18.1 \pm 0.5$ & $23.0 \pm 3.3$ \\
\hline
\end{tabular}

Lysates were from $2 \times 10^{7}$ peripheral blood mononuclear cells, pretreated or not with $1000 \mathrm{U} / \mathrm{ml}$ interferon- $\alpha$.

Radioactivity incorporated is expressed in \% of the radioactivity originally present in ATP.

Comparative estimation of 2'-5'-oligoadenylate synthetase with the assay of Schattner \& Knight (radiobinding assay (15))

In the radiobinding assay, $2{ }^{\prime}-5^{\prime}$-oligoadenylates (trimeric and higher multimeric forms) compete with 2-5A [ $\left.{ }^{32} \mathrm{P}\right] \mathrm{pCp}$ for binding sites of RNaseL. Figure 5 a shows the calibration curve of this reaction using $2 '-5$-oligoadenylate tetramer as substrate in the range from $0.5-5 \mathrm{nmol} 22^{\prime}-5^{\prime}$-oligoadenylate. For comparison of the two assays, the radiobinding assay and the Schattiner assay were carried out in parallel, using different samples with different amounts of cell lysates; the reaction products formed were subsequently estimated according to the methods of the respective test systems. Although there is a linear correlation of the turnover rates in both test systems (coefficient of correlation $r=0.991$ ) (fig. $5 \mathrm{~b}$ ), the $2^{\prime}-5^{\prime}$-oligoadenylate synthetase activities obtained cannot be compaired directly, because different reaction products are measured in the respective assays (Schattner assay: 2'-5'-oligoadenylate cores; radiobinding assay: all classes of 2'-5'-oligoadenylates, except dimeric forms).

Example of clinical application: $2^{\prime}-5^{\prime}$-oligoadenylate synthetase levels in peripheral mononuclear blood cells from children with chronic myelogenous leukaemia and the influence of in vitro treatment with interferon

Peripheral blood mononuclear cells from children with chronic myelogenous leukaemia before chemotherapy showed very low basal levels $(0.1-0.25$, fig. 6). However, after in vitro treatment with interferon, the 2'-5'-oligoadenylate synthetase levels were strongly elevated (up to 35-fold compared to only $2-4$ fold in healthy persons, estimated in this set of experiments). 


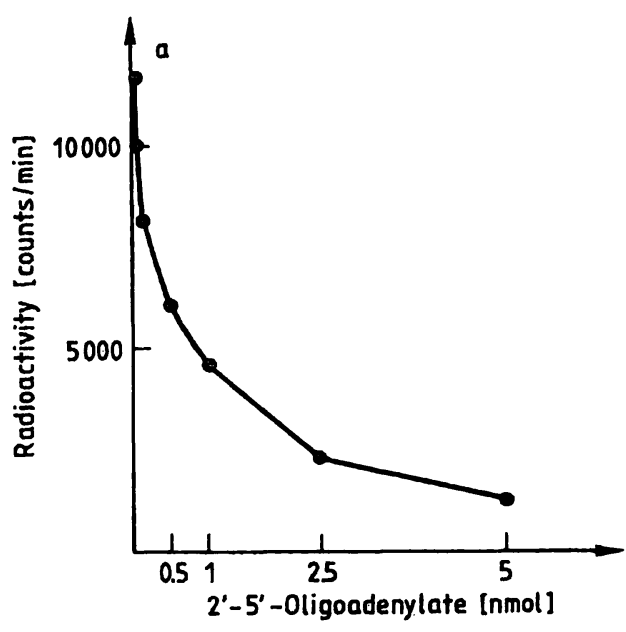

Fig. 5a. Radiobinding assay: calibration curve $x$-axis: nmol 2'-5'-oligoadenylate (tetramer), (calibration standard)

y-axis: amount of $2^{\prime}-5^{\prime}$-oligoadenylate $\left[{ }^{32} \mathrm{P}\right] \mathrm{pCp}$ bound to RNaseL

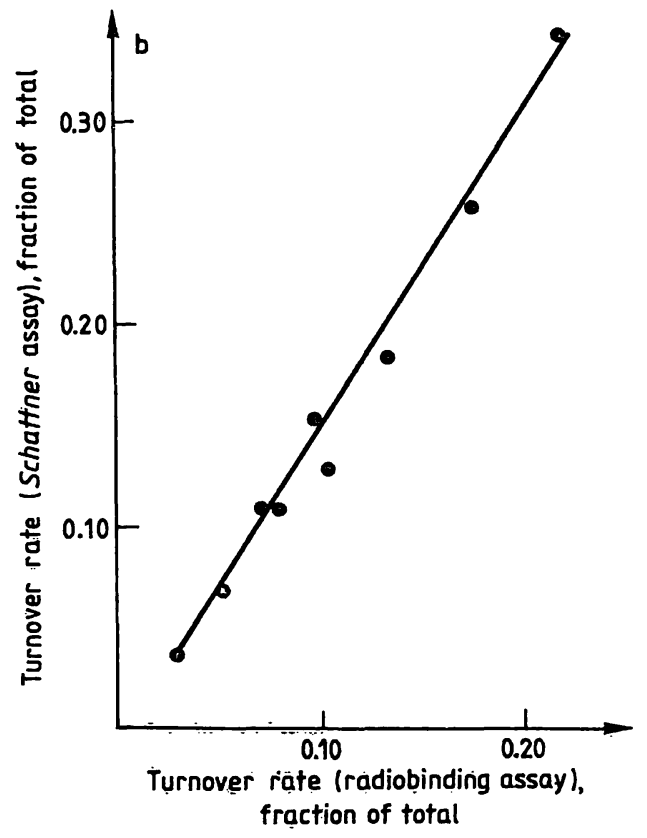

Fig. 5 b. Correlation between the Schattner assay and the radio binding assay. Nine samples containing different amounts of $2^{\prime}-5^{\prime}=$ oligoadenylate synthetase were investigated in parallel. (Calculation was carried out under the approximate assumption that in the mean only 2'-5'-oligoadenylate trimers are formed during the $2^{\prime}-5^{\prime}$-oligoadenylate synthetase reaction).

Therefore, the $2^{\prime}-5$-oligoadenylate synthetase levels finally obtained after in vitro treatment with interferon were the same magnitude as those from healthy donors.

\section{Discussion}

Assays for the determination of $2^{\prime}-5^{\prime}$-oligoadenylate synthetase can be classified as:

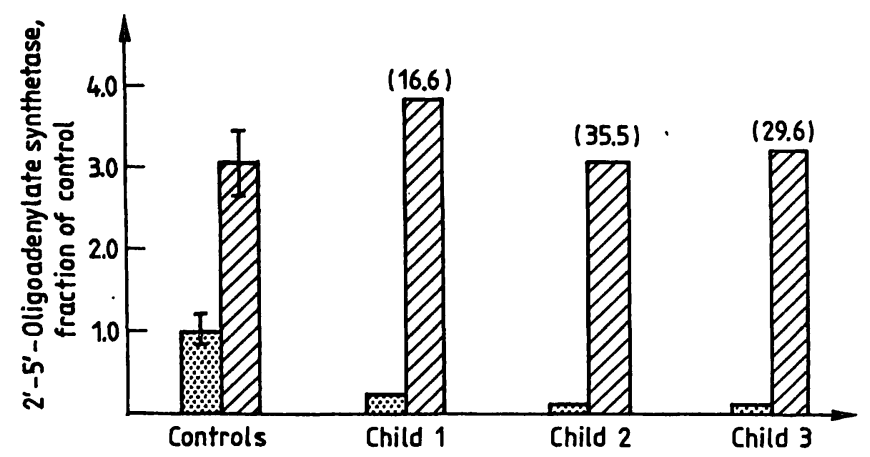

Fig. 6. 2'-5'-Oligoadenylate synthetase catalytic concentrations in peripheral blood mononuclear cells from three different children with chronic myelogenous leukaemia before start of chemotherapy in comparison with healthy controls (1.0).

cells pretrated with interferon overnight

cells incubated in cell culture medium overnight

The values in brackets give the ratio with/without interferon.

1) biological assays (RNA-cleavage assay (21-23), protein synthesis inhibition assay (24))

2) binding assays (radiobinding assay (15), radioimmunoassay (25), enzymeimmunoassay $(26,27))$ and

3) assays that determine $2^{\prime}-5$ '-oligoadenylates formed during the $2^{\prime}-5^{\prime}$-oligoadenylate synthetase reaction $(14,16,17,28,29)$.

We compared four analytical procedures. From the binding assays, we chose the radiobinding assay according to Knight because all the necessary substrates are commercially available. From the third group, three well established assays were carried out (according to Schattner, Lodemann and Ball).

The direct determination of 2'-5'-oligoadenylate synthetase in cell lysates (solution assay, (19)) is restricted by several factors, mainly enzymic reactions that either could consume the substrate of the 2'-5'-oligoadenylate synthetase reaction (ATP) or destroy the products formed $\left(2^{\prime}-5^{\prime}\right.$-oligoadenylates). Additionally, because of the small turnover rate of the $2^{\prime}-5^{\prime}$-oligoadenylate synthetase reaction, long incubation times (several hours) are necessary for a clear signalto-noise background. During this prolonged incubation time, the enzyme is inactivated in solution, but not if it is fixed to a solid matrix. Therefore, $2^{\prime}-5^{\prime}-$ oligoadenylate synthetase is usually isolated from cell lysates using Poly(rI):(rC)-agarose beads. This allows its rapid isolation from cell lysates without co-isolation of ATP- or 2'-5'-oligoadenylate degrading enzymes in amounts that could influence the test procedure (tab. 1). 
Summarizing the advantages and disadvantages of all these procedures, the assay according to Schattner (16) proved - in our view - to be most suitable for routine analysis, mainly with regard to its practicality. Forty to fifty samples in duplicate can be analysed simultaneously, the preparation of alumina colums for separation of $2^{\prime}-5^{\prime}$-oligoadenylate cores from $\left[{ }^{32} \mathrm{P}\right]$ can be performed quickly and easily, and the separation is very effective; blank values are rather low, allowing the determination of $2^{\prime}-5^{\prime}$-oligoadenylate synthetase even for a small turnover of ATP.

This latter point is of special importance, because it is hardly possible to perform the assay under enzymesaturated conditions: Even ATP concentrations as high as $10 \mathrm{mmol} / 1$ (in most assays described ATP concentrations between 1 and $3 \mathrm{mmol} / \mathrm{l}$ are used) do not produce a constant turnover rate in the MichaelisMenten plot (data not shown). Therefore, measurement at a low ATP turnover, provides less opportunity for variations in the velocity of the enzyme reaction. Based on these theoretical considerations and on our own practical experiences with this test system, incubation conditions that lead to an ATP turnover between 5 and $15 \%$ can be recommended for optimal test performance. This can be achieved, e.g. by using extracts from about $4 \times 10^{5}$ peripheral blood mononuclear cells and 5-20 hours incubation time.

The following points concerning the reproducibility of the Schattner assay are worth noting. Using a freshly prepared charge of $\left[{ }^{32} \mathrm{P}\right] \mathrm{ATP}$, the day to day variation of the $2^{\prime}-5^{\prime}$-oligoadenylate synthetase levels are relatively small within the first days, but with increasing prolongation of storage time, the turnover rates decrease; this is probably due to the increasing decomposition of ATP by radiolysis. Because all turnover rates are related to the same internal standard, this fact is not a severe problem.

In the experiments described above, an internal standard was always established for each new set of experiments (i. e. for each new charge of [ $\left.{ }^{32} \mathrm{P}\right] \mathrm{ATP}$ ). However, because 2 '-5'-oligoadenylate synthetase-containing cell lysates can be stored at $-70^{\circ} \mathrm{C}$ for a long period of time, it should be possible to use the same internal standard for several sets of experiments. This is especially recommended if the $2^{\prime}-5^{\prime}$-oligoadenylate synthetase is monitored during long term interferon therapies.

In contrast to its practicability, the Schattner assay has the following severe theoretical limitation. It is not possible to estimate the $2^{\prime}-5^{\prime}$-oligoadenylate synthetase activity exactly, because more than one class of $2^{\prime}-5^{\prime}$-oligoadenylates are formed during the $2^{\prime}-5^{\prime}-$ oligoadenylate synthetase reaction; after treatment with bacterial alkaline phosphatase, only $50 \%$ of the radioactivity originally incorporated into the dimeric form can be registrated (ppp*Ap*A $\rightarrow$ Ap*A + P* $+2 \mathrm{P}$ ), only two thirds of the trimeric form (ppp*Ap*Ap*A $\rightarrow$ Ap*Ap*A $+\mathrm{P}^{*}+2 \mathrm{P}$ ) and so on. Although the $2^{\prime}-5^{\prime}$-oligoadenylate synthetase activity using the Schattiner assay is often expressed as ATP turnover rate, this is not valid, because the composition of the $2^{\prime}-5^{\prime}$-oligoadenylates generated during any $2^{\prime}-5^{\prime}$-oligoadenylate synthetase reaction is unknown. The correct way to express the turnover rate of the $22^{\prime}-5^{\prime}$-oligoadenylate synthetase reaction is therefore to estimate the percent radioactivity incorporated from ATP into 2'-5'-oligoadenylate cores. Because all samples are related to internal standards and are measured in the same way, this evaluation is sufficiently correct.

The problem described does not exist in the two other assays, which are carried out according to the same test principle, but using $\left[{ }^{3} \mathrm{H}\right]$-(adenosine)-labeled ATP.

In the Lodemann assay (14), the 2'-5'-oligoadenylates are separated from $\left[{ }^{3} \mathrm{H}\right]$ adenosine by DEAE-ion exchange chromatography. The only drawback of this assay is that it is not as easy to handle as the Schattner assay (column preparation and elution procedure); this is especially inconvenient when a large number of samples has to be processed. Nevertheless, this test allows the exact determination of the ATP turnover rate and the use of $\left[{ }^{3} \mathrm{H}\right] \mathrm{ATP}$ instead of $\left[{ }^{32} \mathrm{P}\right] \mathrm{ATP}$ has certain advantages.

The third assay in this group, the assay of Ball \& White (17), is most easily performed, because after treatment with bacterial alkaline phosphatase the 2'5 -oligoadenylate cores are only spotted on DEAEion-exchange filters; the $\left[{ }^{3} \mathrm{H}\right]$ adenosine residues are removed from the filters by a simple washing procedure using $\mathrm{H}_{2} \mathrm{O}$. Unfortunately, the sensitivity of this test is limited (high background values). Therefore, small turnover rates cannot be detected and its reproducibility was-in our hand-worse than that of the two other assays described above.

The fourth assay investigated, the radiobinding assay according to Knight (15) is very sensitive, but there are some disadvantages. A calibration curve must always be established, and it is recommended that the test be performed using several sample dilutions in order to get $2^{\prime}-5^{\prime}$-oligoadenylate concentrations well fitted in the calibration curve range. The test is based on the binding of oligoadenylates to RNase $\tilde{L}$ present in high amounts in reticulocyte lysates. However, dimeric $2^{\prime}-5$ '-adenylates do not bind, and therefore, they 
cannot be detected. Thus, the test gives information only about the amount of biologically active oligoadenylates, and an exact determination of the turnover rate of the 2 '-5'-oligoadenylate synthetase reaction is not possible.

Furthermore, we investigated the possibility of using an ATP chemiluminescence assay for the determination of 2'-5'-oligoadenylate synthetase (30), in order to avoid handling radioactivity (data not shown). Although the determination of ATP (its decrease during the $2^{\prime}-5$ '-oligoadenylate synthetase reaction) is more advantageous than the determination of the heterogeneous 2 '-5'-oligoadenylates, a relatively high ATP turnover is necessary in order to get signals clearly distinguishable from the ATP signal at the start of the reaction. However, as already mentioned, it is hardly possible to perform the $2^{\prime}-5^{\prime}$-oligoadenylate synthetase reaction under saturation conditions and therefore, the general applicability of the ATP chemiluminescence assay is restricted.

For clinical investigations, two types of information can be obtained by the $2^{\prime}-5^{\prime}$-oligoadenylate synthetase assay:

1) The basal levels of $2^{\prime}-5^{\prime}$-oligoadenylate synthetase in peripheral mononuclear blood cells from patients, expressed relative to standards (healthy person, set as 1.0).

2) The elevation factor, expressed as the ratio of $2^{\prime}$ $5^{\prime}$-oligoadenylate synthetase levels before and after in vitro treatment of cells with interferon. The determination of this factor provided very useful additional information, e. g. compared with values obtained from healthy persons, this factor was found to be reduced in peripheral mononuclear blood cells from patients with acquired immunodeficiency syndrome (AIDS) (8) or from children with severe immunodeficiency syndrome (20). The elevation factor is influenced by several parameters (type of interferon; type of foetal calf serum used

\section{References}

1: Johnston, M. I. \& Torrence, P. F. (1984) In: Interferon, Vol. 3 (Friedmann, R. M., ed.) Elsevier, Amsterdam - New York-Oxford, pp. 189-298.

2. Sen, G. C. (1984) Pharmac. Ther. 24, 235-257.

3. Eppstein, D. A., Schryver, B. B., Marsh, Y. V., Larsen, M. A. \& Kuahara, C. G. (1983) J. Interferon Res. 3, 305311.

4. Kimchi, A. (1981) J. Interferon Res. 1, 559-570.

5. Chousterman, S., Chousterman, M., Poitrine, A., Chaput, J. C. \& Thang, M. N. (1985) Prog. Clin. Biol. Res. 202, $423-430$. for incubation; incubation time); additionally, it made a considerable difference to the results if the cell lysate of the peripheral blood mononuclear cells, which was not treated with interferon, was prepared immediately after isolation from peripheral blood or after a simultaneous overnight incubation using an interferon-free medium. In all experiments described here, untreated peripheral blood mononuclear cells were used after overnight incubation.

In our own investigations described above, the basal levels of 2'-5'-oligoadenylate synthetase in peripheral blood mononuclear cells from children with chronic myelogenous leukaemia were found to be strongly reduced, compared with healthy controls. This is in agreement with the suggestion that $2^{\prime}-5^{\prime}$-oligoadenylate snythetase (as part of the antiproliferative 2'-5'oligoadenylate system) is low in undifferentiated and proliferating cells. However, these low basal levels can be elevated drastically after in vitro treatment with interferon. Independently of its diagnostic significance, the biological importance of this elevation remains to be clarified, because the elevation of $2^{\prime}-5^{\prime}$ oligoadenylate synthetase alone is not in itself sufficient to produce antiproliferative (or antiviral) effects; oligoadenylates can be formed and the 2'-5'-oligoadenylate system becomes operative, only in the presence of dsRNA. It can be speculated that mRNAs coding for proteins engaged in proliferative processes (e.g. from oncogenes or growth factors) could serve as target molecules for the selective attachment and activation of the $2^{\prime}-5^{\prime}$-oligoadenylate synthetase, provided that these mRNAs can form partial double stranded chains (e.g. by chain refolding). Such a mechanism is possibly responsible for the selective degradation of the myc-oncogene mRNA, observed after interferon treatment of lymphoblastoid Daudi cells $(31-34)$. Whether this principle may also play a role in chronic myelogenous leukaemia, or other malignant diseases influenced by interferon, is still an open question.
6. Schattner, A., Wallach, D., Berlin, G., Hahn, T., Levin, S. \& Revel, M. (1981) Lancet II, 497-499.

7. Morag, A., Tobi, M., Ravid, Z., Revel, M., Schattner, A. (1982) Lancet $I, 744$.

8. Preble, O. T., Tze-Jou Yeh, Silverman, R. H., Kippel, J. H., Strauss, S. E. \& Gelman, E. P. (1985) Prog. Clin. Biol. Res. 202, 405-422.

9. Read, S. E., Le Brocq, F. J. \& Williams, G. (1985) Prog. Clin. Biol. Res. 202, 439-447.

10. Schattner, A., Wallach, D., Merlin, G., Hahn, T., Levin, S., Ramot, B. \& Revel, M. 81982) J. Interferon Res. 2, $355-361$. 
11. Justesen, P., Kokland, P. \& Hokland, M. (1985) Prog. Clin. Biol. Res. 202, 439-447.

12. Koscielniak, E., Bruchelt, G., Treuner, J., Uchansks-Ziegler, B., Dopfer, R., Vallbracht, A. \& Niethammer, D. (1987) Bone Marrow Transplantation 1, 379-387.

13. Merritt, J. A., Meltzer, D. M., Ball, L. A. \& Borden, E. C. (1985) Prog. Clin. Biol. Res. 202, 423-430.

14. Lodemann, E., Kornhuber, B., Gerein, V. \& von Illberg, Ch. (1984) J. Interferon Res. 4, 283-290.

15. Knight, M., Cayley, P. J., Silverman, R. H., Wreschner, D. H., Gilbert, C. S., Brown, R. E. \& Kerr, I. M. (1980) Nature 288, 189-192.

16. Schattner, A., Merlin, G., Wallach, D., Rosenberg, H., Bino, T., Hahn, S., Levin, S. \& Revel, M. (1981) J. Interferon Res. 1, 587-594.

17. Ball, L. A. \& White, C. N. (1979) In: Regulation of Macromolecular Synthesis by Low Molecular Weight Mediators (Koch, G. \& Richter, D., eds.) Academic Press pp. 303-317.

18. Schmidt, A., Chernajovsky, Y., Shulman, L., Federman, P., Berissi, H. \& Revel, M. (1979) Proc. Natl. Acad. Sci. USA 76, 4788-4792.

19. Minsk, A., Benvin, S., Maroney, P. A. \& Baglioni, C. (1979) J. Biol. Chem. 254, 5058-5064.

20. Williams, B. R. G., Read, S. E. \& Gelfand, E. W. (1984) Clin. Exp. Immunol. 56, 34-38.

21. Baglioni, C., D'Alessandro, S. B., Nilsen, T. W., Den Hartog, J. A., Crea, R. \& Van Boom, J. H. (1981) J. Biol. Chem. 256, 3253-3257.

22. Williams, B. R. G., Brown, R. E., Gilbert, C. S., Golgher, R. R. \& Kerr, I. R. (1979) Nature 282, 582-586.
23. Wreschner, D. H., James, T. C., Silverman, R. H. \& Kerr, I. M. (1981) Nucl. Acid Res. 9, 1571-1581.

24. Williams, B. R. G., Brown, R. E., Gilbert, C. S., Golgher, R. R., Wreschner, D. H., Silverman, R. H. \& Kerr, I. M. (1981) Methods in Enzymology 79, 199-208.

25. Cailla, H., Le Borne de Kaoul, C., Roux, D., Delaage, $M$. \& Marti, J. (1982) Proc. Natl. Acad. Sci. USA 79, 47424746.

26. Johnston, M. I., Imai, J., Lesiak, K. \& Torrence, P. F. (1983) Biochemistry 22, 3453-3460.

27. Luxembourg, A., Trujillo, M., Laürēnce, L., Sämuel, D., Nicolas, M., Roux, D., Cailla, H. \& Marti, J. (1985) Prog. Clin. Biol. Rès. 202, 123=131.

28. Minsk, M. A., Benvin, S. \& Baglioni, C. (1980) J. Biol. Chem. 255, $5031-5035$.

29. Justesen, J., Ferbus, D. \& Thang, M. N. (1980) Nucl. Acid Res. 8, 3073-3085.

30. Bruchelt, G., Beck, J., Kosielniak, E., Treuner, J. \& Niet; hammer, D. (1985) J. Clin. Chem. Clin. Biochem. 23, 595596.

31. Clemens, M. (1985) Nature 313, 531-532.

32. Dani, Ch., Mechti, N., Piechazyk, M., Lebleu, B., Jeanteur, P. H. \& Blanchard, J. M. (1985) Proc. Natl. Acad. Sci. USA 82, 4896-4899.

33. Jonak, G. J. \& Knight, E. (1984) Proc. Natl. Acad. Sci. USA $81,1747-1750$.

34. Knight, E. jr., Anton, E. D., Fahey, D., Friedland, B. K. \& Jonak, G. J. (1985) Proc. Natl. Acad. Sci. USA 82, $1151-1154$.

Dr. G. Bruchelt

Univ. Kinderklinik

Abt. Hämatologie

Rümelinstraße 23

D-7400 Tübingen 